\title{
PENGARUH DIMENSI RELATIONSHIP MARKETING TERHADAP KEPUASAN DAN LOYALITAS NASABAH \\ (Studi Kasus Pada BPR Argodana Pudak Payung Semarang)
}

\author{
Arum Istiqomawati \\ Universitas Islam Sultan Agung Semarang \\ arum_ksusb@yahoo.com
}

\begin{abstract}
The purpose of this research is to analyze and determine the effect of communication, partnership, trust, conflict complain on customer satisfaction and to analyze and determine the effect of communication, partnership, trust, conflict complain and customer satisfaction on customer loyalty. The population in this study is the BPR customers Argodana Pudak Umbrella Semarang, while the population as much as 96 respondents obtained by using purposive sampling technique. The type of data used is primary data, using the method of data collection questionnaire. The results of analysis by using path analysis is communication, partnership, trust, conflict complain effect on customer satisfaction. Communication, partnership, trust, complain conflict and affect customer satisfaction on customer loyalty. customer satisfaction is among the intervening variablesinfluence of partnership on customer loyalty, however, customer satisfaction is not an intervening variable between the influence of communication, trust and conflict complaint on customer loyalty.
\end{abstract}

Keywords: Communication, Partnership, Trust, Conflict Complain, Satisfaction and Customer Loyalty

\section{PENDAHULUAN}

Permintaan masyarakat terhadap kebutuhan jasa pada masa sekarang ini mengalami peningkatan yang sangat pesat. Bidang usaha di sektor jasa mulai dibangun dan dikembangkan oleh para pengusaha, baik bidang usaha jasa pendukung produk yang dijualnya maupun bidang usaha yang menjual jasa murni. Menurut Kotler (2009), jasa adalah setiap tindakan atau perbuatan yang dapat ditawarkan oleh suatu pihak kepada pihak lain yang pada dasarnya bersifat tidak berwujud (intangible) dan tidak menghasilkan kepemilikan sesuatu. Jasa tidak dapat dilihat, diraba, dicium, didengar, dan dirasakan seperti halnya produk nyata, sehingga penilaian terhadap jasa berbeda dengan penilaian terhadap produk.
Perkembangan jasa lembaga perbankan dari tahun ke tahun semakin banyak bermunculan. Hal ini tercermin dari persaingan lembaga perbankan untuk dapat memenangkan nasabah, oleh karena itu, hal utama yang harus diprioritaskan oleh usaha jasa lembaga perbankan adalah mengutamakan kepuasan nasabah, sehingga pada akhirnya nasabah akan merasa percaya menggunakan jasa lembaga perbankan. Guna memenangkan persaingan, maka pihak perbankan berusaha untuk melayani nasabah dengan lebih baik, agar nasabah merasa puas dan loyal. Dalam mengevaluasi kepuasan dan ketidakpuasan terhadap suatu perusahaan tertentu, faktor penentu yang digunakan bisa berupa kombinasi dari Relationship 
marketing.

Relationship marketing adalah strategi bisnis dan pemasaran yang memberdayakan kekuatan keinginan pelanggan, relationship marketing meliputi aspek kepercayaan, komitmen, komunikasi dan penanganan kaluhan. Dengan kata lain, suatu kemitraan jangka panjang dengan pelanggan dan secara menerus sehingga diharapkan dapat terjadi bisnis ulangan.

Sejalan dengan konteks relation ship marketing, kepercayaan atas merek akan berpengaruh terhadap loyalitas hal ini dikarenakan kepercayaan menimbulkan suatu hubungan timbal balik yang bernilai sangat tinggi. Jadi dapat dikatakan bahwa loyalitas adalah proses yang kesinambungan sebagai akibat dari terbentuknya kepercayaan atas merek. Semakin tinggi kepercayaan konsumen, maka loyalitas konsumen akan semakin meningkat, sebab konsumen yang percaya enggan untuk berlaih ke perusahaan lain yang belum tentu akan mendapatkan pelayanan yang labih baik.

Konsep valued relationship menujukkan bahwa pelanggan akan memiliki komitmen yang kuat jika hubungan yang dilakukan di anggap penting. Komitmen perusahaan menunjukkan bahwa perusahaan menganggap kelanjutan hubungan dengan pembelinya merupakan hal yang harus dipelihara dan dipertahankan dengan baik (Ellena, 2011). Komitmen dalam konsep long term relationship, memegang peranan yang sangat penting karena hubungan jangka panjang paling banyak didasarkan kepada komitmen kedua belah pihak. Komitmen adalah perluasan dari kebutuhan untuk mempertahankan relation ship yang disebabkan oleh adanya manfaat ekonomi dan switching cost, sehingga loyalitas konsumen akan terbentuk.

Komunikasi pemasaran adalah sangat penting, karena untuk mempertahankan pelanggan lama dan menarik pelanggan baru eprusahaan harus melakukan komunikasi yang sesuai dengan karakter konsumen sasarannya. Komunikasi menurut Purwanto (2003) adalah suatu proses pertukaran informasi antara individu ataupun konsumen melalui suatu sistem yang lazim (biasa), baik dengan simbol-simbol, sinyal-sinyal maupun perilaku atau tindakan. Informasi yang di dapatkan konsumen biasanya akan berhubungan dengan keputusan yang diambil konsumen untuk berkunjung atau mengambil keputusan untuk memilih tetap loyal terhadap perusahaan.

Membangun hubungan jangka panjang yang kokoh dengan pelanggan memerlukan usaha penuh konsentrasi dari semua karyawan dan pihak manajemen untuk mengetahui apa yang memuaskan pelanggan dan apa yang dihargai oleh palnggan, karena apa yang dihargai oleh pelanggan lebih luas dari apa yang tampaknya di sadari oleh banyak manajer. Relationship marketing melibatkan penciptaan, pemeliharaan dan peningkatan hubungan yang kuat dengan pelanggan, relationship marketing berorientasi pada jangka waktu yang panjang dan bertujuan untuk memberikan nilai pada pelanggan mengenai produk atau jasa dan ukuran kesuksesan adalah kepuasan pelanggan pada jangka panjang berupa penciptaan loyalitas pelanggan (Kotler dan Amstrong, 2009).

Relationship marketing di butuhkan untuk semua jenis perusahaan tidak terkecuali BPR Argodana Pudak Payung Semarang. Seiring dengan perkembangan bisnis di bidang BPR yang semakin meningkat di Indonesia, BPR Argodana Pudak Payung Semarang harus bersaing dengan lembaga keuangan lainnya. Permasalahan terjadi kerena target penjualan BPR Argodana Pudak Payung Semarang yang ditetapkan oleh perusahaan selama tahun 2012-2014 tidak tercapai. Hal ini mengindikasikan bahwa hubungan antara klien dengan perusahaan kurang terwujud (Relationship marketing) kurang baik, sehingga kepuasan pelanggan dan loyalitas pelanggan juga menurun. Hasil penelitian terdahulu oleh 
Ellena (2011), Samuel (2012), Hadinata (2013), membuktikan bahwa relationship marketing berpengaruh signifikan terhadap kepuasan dan loyalitas, sedangkan Murti (2013), Maulidi dan Rofiq (2012), membuktikan bahwa relationship marketing berpengaruh tidak signifikan terhadap kepuasan dan loyalitas

\section{KAJIAN PUSTAKA}

\section{Komunikasi, Kepuasan dan Loyalitas}

Dalam kegiatan bisnis, komunikasi pemasaran adalah sangat penting, karena untuk mempertahankan pelanggan lama dan menarik pelanggan baru eprusahaan harus melakukan komunikasi yang sesuai dengan karakter konsumen sasarannya. Komunikasi menurut Kenneth dan Gerry dalam Umar (2002) adalah penyampaian informasi antara dua orang atau lebih, yang juga meliputi pertukaran informasi antar manusia.

Hasil penelitian Murti (2013), membuktikan bahwa komunikasi berpengaruh positif terhadap kepuasan konsumen, apabila komunikasi semakin meningkat, maka loyalitas konsumen akan semakin meningkat. Hasil penellitian Ellena (2011), juga membuktikan bahwa komunikasi berpengaruh positif terhadap kepuasan konsumen, apabila komunikasi semakin meningkat, maka loyalitas konsumen akan semakin meningkat. Berdasarkan uraian di atas, maka dapat dikemukan hipotesis :

$\mathrm{H} 2$ : Komunikasi berpengaruh positif terhadap kepuasan konsumen

Hasil penelitian Murti (2013),
membuktikan bahwa komunikasi
berpengaruh positif terhadap loyalitas
konsumen, apabila komunikasi semakin
meningkat, maka loyalitas konsumen akan
semakin meningkat. Hasil penellitian Ellena
(2011), jugamembuktikan bahwakomunikasi
berpengaruh positif terhadap loyalitas
konsumen, apabila komunikasi semakin
meningkat, maka loyalitas konsumen akan
semakin meningkat. Berdasarkan uraian di

atas, maka dapat dikemukan hipotesis :

$\mathrm{H} 2$ : Komunikasi berpengaruh positif terhadap loyalitas konsumen

\section{Kemitraan, Kepuasan dan Loyalitas}

Tjiptono (2006), mendefinisikan bahwa kemitraan merupakan hasrat atau keinginan kuat untuk mempertahankan dan melanjutkan relasi yang dipandang penting dan bernilai jangka panjang. Kemitraan menurut Sunarto (2006), adalah hubungan emosional atau psikologis dengan merek dalam suatu golongan produk. secara menyeluruh, komitmen mereka yang sering etrjadi dalam produk dengan keterlibatan tinggi yang melambangkan konsep diri, nilai dan kebutuhan konsumen.

Kemitraan dalam hubungannya dengan penyedia jasa dan pelanggan didefinisikan sebagai suatu janji yang diungkapkan dari berkelanjutan hubungan dengan pihak lain. Konsumen merasakan sejumlah perasaan terhadap kemitraan pada hubungan yang telah tercipta dengan para penyedia jasa. Kemitraan dalam konsep long term relationship, memegang peranan yang sangat penting karena hubungan jangka panjang paling banyak didasarkan kepada komitmen kedua belah pihak. Kemitraan adalah perluasan dari kebutuhan untuk mempertahankan relation ship yang disebabkan oleh adanya manfaat ekonomi dan switching cost.

Hasil penelitian Murti (2013), membuktikan bahwa kemitraan berpengaruh positif terhadap kepuasan konsumen, apabila kemitraan semakin meningkat, maka kepuasan konsumen akan semakin meningkat. Hasil penellitian Ellena (2011), juga membuktikan bahwa komitmen berpengaruh positif terhadap kepuasan konsumen, apabila kemitraan semakin meningkat, maka kepuasan konsumen akan semakin meningkat. Berdasarkan uraian di atas, maka dapat dikemukan hipotesis :

H3: Kemitraan berpengaruh positif terhadap kepuasan konsumen

Hasil penelitian Murti (2013),


membuktikan bahwa kemitraan berpengaruh positif terhadap loyalitas konsumen, apabila kemitraan semakin meningkat, maka loyalitas konsumen akan semakin meningkat. Hasil penellitian Ellena (2011), juga membuktikan bahwa komitmen berpengaruh positif terhadap loyalitas konsumen, apabila kemitraan semakin meningkat, maka loyalitas konsumen akan semakin meningkat. Berdasarkan uraian di atas, maka dapat dikemukan hipotesis :

H3 : Kemitraan berpengaruh positif terhadap loyalitas konsumen

\section{Kepercayaan (Trust), Kepuasan dan Loyalitas}

Kepercayaan menurut Mowen (2002) adalah semua pengetahuan yang dimiliki oleh konsumen dan semua kesimpulan yang dibuat oleh konsumen tentang obyek, atribut dan manfaatnya. Maksud dari obyek disini adalah berupa produk, orang, perusahaa dan segala sesuatu dimana seseorang memiliki kepercayaan dan sikap.

Sejalan dengan konteks relation ship marketing, kepercayaan atas merek akan berpengaruh terhadap loyalitas hal ini dikarenakan kepercayaan menimbulkan suatu hubungan timbal balik yang bernilai sangat tinggi. Jadi dapat dikatakan bahwa loyalitas adalah proses yang kesinambungan sebagai akibat dari terbentuknya kepercayaan atas merek.

Hasil penelitian Murti (2013), membuktikan bahwa kepercayaan berpengaruh positif terhadap kepuasan konsumen, apabila kepercayaan konsumen semakin meningkat, maka kepuasan konsumen akan semakin meningkat. Hasil penellitian Septria (2012), juga membuktikan bahwa kepercayaan berpengaruh positif terhadap kepuasan konsumen, apabila kepercayaan konsumen semakin meningkat, maka kepuasan konsumen akan semakin meningkat. Berdasarkan uraian di atas, maka dapat dikemukan hipotesis :

H5: Kepercayaan berpengaruh positif terhadap kepuasan konsumen
Hasil penelitian Murti (2013), membuktikan bahwa kepercayaan berpengaruh positif terhadap loyalitas konsumen, apabila kepercayaan konsumen semakin meningkat, maka loyalitas konsumen akan semakin meningkat. Hasil penellitian Septria (2012), juga membuktikan bahwa kepercayaan berpengaruh positif terhadap loyalitas konsumen, apabila kepercayaan konsumen semakin meningkat, maka loyalitas konsumen akan semakin meningkat. Berdasarkan uraian di atas, maka dapat dikemukan hipotesis :

H6: Kepercayaan berpengaruh positif terhadap loyalitas konsumen

\section{Complain Konflik}

Pada hakekatnya ada dua tujuan utama pelanggan menyampaikan komplain (Tjiptono, 2006). Pertama, untuk menutupi kerugian ekonomis, yang biasanya diwujudkan dengan melakukan voice response atau third party response. Tujuan kedua adalah untuk memperbaiki citra diri (self-image). Apabila citra diri pelanggan berkaitan erat dengan pembelian produk tertentu, maka ketidakpuasan terhadap produk yang dibeli tersebut akan menurunkan citra diri pelanggan yang bersangkutan untuk mengangkat kembali citra dirinya, maka pelanggan tersebut biasanya melakukan tindakan-tindakan voice response atau third party response.

Menurut Tjiptono (2006) penanganan komplain secara efektif memberikan peluang pelanggan yang tidak puas menjadi puas dan pada akhirnya akan merasa loyal (membeli kembali). Berdasarkan uraian di atas, maka dikemukakan hipotesis sebagai berikut :

$\mathrm{H} 7$ : Complain konflik berpengaruh positif terhadap kepuasan pelanggan

\begin{tabular}{llr}
\multicolumn{1}{c}{ Hasil penelitian } & \multicolumn{1}{c}{ Murti } & (2013), \\
membuktikan bahwa complain & konflik \\
berpengaruh positif & terhadap loyalitas \\
konsumen, apabila kepercayaan konsumen & lonak \\
semakin meningkat, maka loyalitas
\end{tabular}

Pengaruh Dimensi Pengaruh Dimensi Relationship ... (Arum Istiqomawati) 
konsumen akan semakin meningkat. Berdasarkan uraian di atas, maka dapat dikemukan hipotesis :

H8 : Komplain konflik berpengaruh positif terhadap loyalitas konsumen

HasilpenelitianMurti(2013), membuktikan bahwa kepuasan konsumen berpengaruh positif terhadap loyalitas konsumen, apabila kepuasan konsumen semakin meningkat, maka loyalitas konsumen akan semakin meningkat. Berdasarkan uraian di atas, maka dapat dikemukan hipotesis :

H9 : Kepuasan konsumen berpengaruh positif terhadap loyalitas konsumen dalam penelitian ini adalah berusia minimal 17 tahun, telah menggunakan jasa di BPR Argodana Pudak Payung Semarang minimal 1 tahun. Jumlah sampel 96 responden.

\section{Metode Analisis Data}

Untuk menguji pengaruh variabel intervening digunakan metode analisis jalur (Path Analysis). Analisis jalur merupakan perluasan dari analisis regresi linear berganda, atau analisis jalur adalah penggunaan analisis regresi untuk menaksir hubungan kausalitas antar variabel ( model

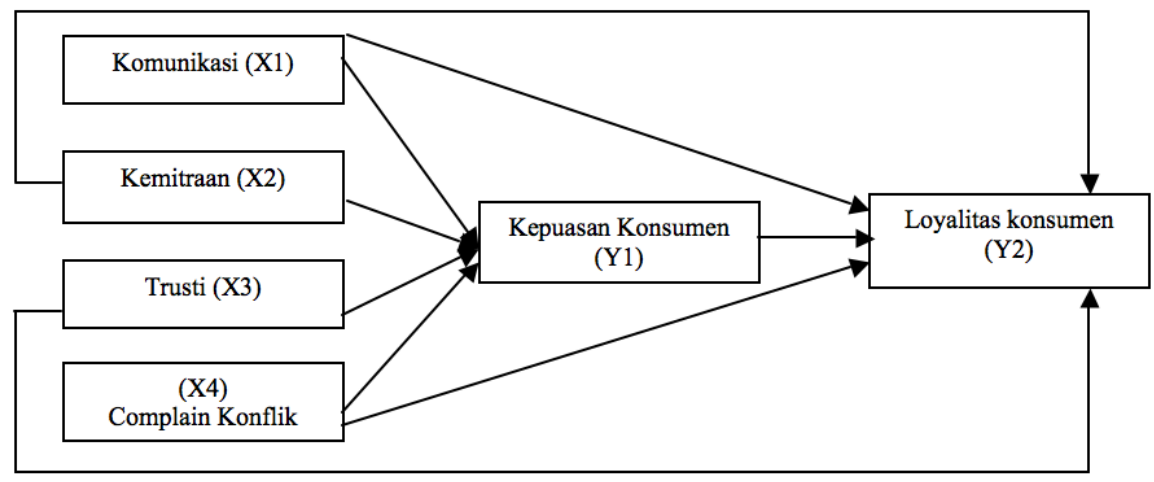

Gambar 1 Kerangka Pikir

\section{Kerangka Pikir \\ Metode Penelitian \\ Populasi dan Sampel}

Setiap mengadakan penelitian terlebih dahulu menentukan obyek apa yang akan diteliti dan siapa yang menjadi populasinya. Populasi adalah jumlah keseluruhan dari unit analisis yang ciri-cirinya akan diduga. (Masri Singarimbun, 2005:152) Dalam penelitian ini yang menjadi populasinya adalah nasabah BPR Argodana Pudak Payung Semarang.

Sampel adalah bagian kecil dari populasi yang karakteristiknya hendak diselidiki dan dianggap dapat mewakili dari keseluruhan populasi. Dalam hal ini metode yang digunakan untuk mengambil sampel adalah purposive sampling, yaitu teknik penentuan sampel berdasarkan kriteria tertentu. Kriteria casual ) yang telah ditetapkan sebelumnya berdasarkan teori. Dalam penelitian ini proses penghitungan dibantu dengan program SPSS. Adapun persamaan umum dalam menghitung regresi berganda adalah: $K P n=a+b_{1} K O+b_{2} K M+b_{3} T R+b_{4} C K+e 1$

$$
\begin{gathered}
L P=a+b_{1} K O+b_{2} K M+b_{3} T R+b_{4} C K+b_{5} \\
K P n+e 2
\end{gathered}
$$

Di mana :

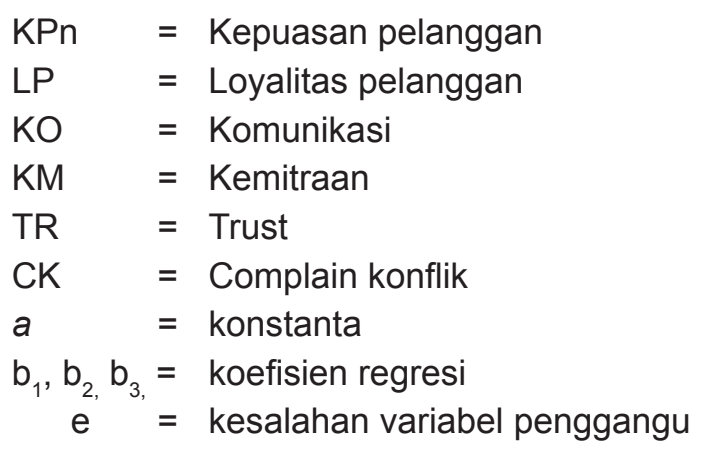


Tabel 1. Definisi Operasional

\begin{tabular}{|c|c|c|c|}
\hline Variabel & Definisi Konsep & Indikator & $\begin{array}{c}\text { Skala } \\
\text { Pengukuran }\end{array}$ \\
\hline Komunikasi & $\begin{array}{l}\text { Komunikasi menurut } \\
\text { Purwanto (2003) adalah } \\
\text { suatu proses pertukaran } \\
\text { informasi antara individu } \\
\text { ataupun konsumen } \\
\text { melalui suatu sistem } \\
\text { yang lazim (biasa), baik } \\
\text { dengan simbol-simbol, } \\
\text { sinyal-sinyal maupun } \\
\text { perilaku atau tindakan. }\end{array}$ & $\begin{array}{l}\text { - } \\
\text { Adanya komunikasi } \\
\text { timbal balik dari } \\
\text { nasabah dengan bank } \\
\text { - } \quad \text { Bahasa yang di } \\
\text { pergunakan petugas } \\
\text { pelayanan mudah di } \\
\text { mengerti oleh nasabah } \\
\text { - } \\
\text { Komunikasi di lakukan } \\
\text { dengan bahasa yang } \\
\text { sopan }\end{array}$ & $\begin{array}{l}\text { skala ordinal Likert } \\
1-5\end{array}$ \\
\hline Kemitraan & $\begin{array}{l}\text { Tjiptono (2006), } \\
\text { mendefinisikan } \\
\text { bahwa kemitraan } \\
\text { merupakan hasrat atau } \\
\text { keinginan kuat untuk } \\
\text { mempertahankan dan } \\
\text { melanjutkan relasi yang } \\
\text { dipandang penting dan } \\
\text { bernilai jangka panjang }\end{array}$ & $\begin{array}{ll}\text { - } & \text { Bangga menjadi } \\
\text { nasabah } \\
\text { - } & \text { Nasabah mempunyai } \\
& \text { rasa memiliki } \\
\text { - } & \text { Bank Memperhatikan } \\
& \text { keberhasilan jangka } \\
& \text { panjang }\end{array}$ & $\begin{array}{l}\text { skala ordinal Likert } \\
1-5\end{array}$ \\
\hline Kepercayaan & $\begin{array}{l}\text { Kepercayaan menurut } \\
\text { Mowen (2002) adalah } \\
\text { semua pengetahuan yang } \\
\text { dimiliki oleh konsumen } \\
\text { dan semua kesimpulan } \\
\text { yang dibuat oleh } \\
\text { konsumen tentang obyek, } \\
\text { atribut dan manfaatnya }\end{array}$ & $\begin{array}{ll}\text { - } & \text { Reputasi yang dimiliki } \\
\text { produk bank } \\
\text { - } & \text { Keamanan dan } \\
\text { kenyamanan dalam } \\
\text { menggunakan produk } \\
\text { bank } \\
\text { - } \quad \text { Manfaat yang ada pada } \\
\text { produk bank }\end{array}$ & $\begin{array}{l}\text { Skala ordinal Likert } \\
1-5\end{array}$ \\
\hline $\begin{array}{l}\text { Complain } \\
\text { Conflict }\end{array}$ & $\begin{array}{l}\text { Manajemen komplain } \\
\text { merupakan salah satu } \\
\text { determinan signifikan } \\
\text { kepuasan dan loyalitas } \\
\text { pelanggan. Upaya } \\
\text { mempertahankan jalinan } \\
\text { relasi dengan pelanggan } \\
\text { yang tidak puas melalui } \\
\text { pengelolaan komplain } \\
\text { telah menjadi fokus } \\
\text { utama sebagian besar } \\
\text { strategi retensi pelanggan } \\
\text { (Kotler, 2005) }\end{array}$ & $\begin{array}{ll}\text { - } & \text { Empati terhadap } \\
\text { pelanggan yang marah } \\
\text { - } \quad \text { Kecepatan dalam } \\
\text { menanggani pelanggan } \\
\text { - } \quad \text { Kemudahan bagi } \\
\text { konsumen untuk } \\
\text { menghubungi bank }\end{array}$ & $\begin{array}{l}\text { skala ordinal Likert } \\
1-5\end{array}$ \\
\hline
\end{tabular}

Kriteria pengujian : Apabila nilai thitung $<\mathrm{t}$ tabel atau signifikasi $>0,05$, maka $\mathrm{Ho}$ diterima, artinya tidak ada pengaruh variabel bebas terhadap variabel terikat.

Apabila nilai $\mathrm{t}$ hitung $>\mathrm{t}$ tabel atau signifikasi $<0,05$, maka Ha diterima, artinya ada pengaruh variabel bebas terhadap variabel terikat.

\section{HASIL DAN PEMBAHASAN}

Untuk penelitian ini data yang terkumpul dengan menggunakan Path Analisis (analisis jalur). Dalam penelitian ini teknik analisis jalur path dilakukan dengan menggunakan 
analisis regresi linier berganda sebagai berikut :

$$
\begin{array}{ll}
\text { a. } & Y_{1}=0,217 X_{1}+0,412 X_{2}+0,209 X_{3}+ \\
& 0,122 X_{4}+e 1 \\
\text { b. } & Y_{2}=0,131 X_{1}+0,108 X_{2}+0,143 X_{3}+ \\
& 0,109 X_{4}+0,393 Y_{1}+e 2
\end{array}
$$

Berdasarkan dua persamaan regresi di atas, maka dapat digambarkan analisis path berpengaruh terhadap loyalitas nasabah. Dengan demikian dapat disimpulkan bahwa Ho ditolak dan $\mathrm{Ha}$ diterima, sehingga hipotesis yang menyatakan dugaan adanya

\begin{tabular}{|c|c|c|c|c|c|c|c|c|c|}
\hline $\begin{array}{c}\text { Variabel } \\
\text { Endogen }\end{array}$ & $\begin{array}{l}\text { Variabel } \\
\text { Eksogen }\end{array}$ & $\mathrm{R}$ & $\begin{array}{l}\text { Adj. R } \\
\text { Square }\end{array}$ & $\mathrm{E}$ & $\begin{array}{l}\text { Koef } \\
\text { Jalur }\end{array}$ & $t$ & P & $\begin{array}{l}\text { Efek } \\
\text { Lsng }\end{array}$ & $\begin{array}{l}\text { Efek } \\
\text { Tdk } \\
\text { Isq }\end{array}$ \\
\hline$Y_{1}$ & $\begin{array}{l}X_{1} \\
X_{2} \\
X_{3} \\
X_{4}\end{array}$ & 0,895 & 0,792 & 0,847 & $\begin{array}{l}0,217 \\
0,412 \\
0,209 \\
0,122\end{array}$ & $\begin{array}{l}2,323 \\
4,091 \\
2,303 \\
2,297\end{array}$ & $\begin{array}{l}0,022 \\
0,000 \\
0,024 \\
0,030\end{array}$ & $\begin{array}{l}0,217 \\
0,412 \\
0,209 \\
0,122\end{array}$ & $\begin{array}{l}- \\
- \\
- \\
-\end{array}$ \\
\hline$Y_{2}$ & $\begin{array}{l}X_{1} \\
X_{2} \\
X_{3} \\
X_{4} \\
Y_{1}\end{array}$ & 0,919 & 0,836 & 0,650 & $\begin{array}{l}0,131 \\
0,108 \\
0,143 \\
0,109 \\
0,393\end{array}$ & $\begin{array}{l}2,710 \\
2,564 \\
2,786 \\
2,590 \\
3,072\end{array}$ & $\begin{array}{l}0,008 \\
0,017 \\
0,007 \\
0,016 \\
0,004\end{array}$ & $\begin{array}{l}0,131 \\
0,108 \\
0,143 \\
0,109 \\
0,393\end{array}$ & $\begin{array}{l}0,083 \\
0,162 \\
0,082 \\
0,048 \\
-\end{array}$ \\
\hline
\end{tabular}
pengaruh komunikasi terhadap loyalitas nasabah dapat diterima.

Tabel 2. Hasil Analisis Jalur

Sedangkan hasil analisisnya disajikan dalam tabel 2 .

\section{Pengaruh komunikasi terhadap kepuasan nasabah}

Berdasarkan hasil pengolahan SPSS, di peroleh nilai signifikasi pengaruh komunikasi terhadap kepuasan nasabah sebesar 0,022 . Nilai signifikasi $0,022<0,05$, dengan demikian dapat diartikan bahwa komunikasi berpengaruh terhadap kepuasan nasabah. Dengan demikian dapat disimpulkan bahwa Ho ditolak dan $\mathrm{Ha}$ diterima, sehingga hipotesis yang menyatakan dugaan adanya pengaruh komunikasi terhadap kepuasan nasabah dapat diterima

\section{Pengaruh komunikasi terhadap loyalitas nasabah}

Berdasarkan hasil pengolahan SPSS, di peroleh nilau signifikasi pengaruh komunikasi terhadap loyalitas nasabah sebesar 0,008. Nilai signifikasi $0,008<0,05$, dengan demikian dapat diartikan bahwa komunikasi

\section{Pengaruh Kemitraan terhadap kepuasan nasabah}

Berdasarkan hasil pengolahan SPSS, di peroleh nilau signifikasi pengaruh kemitraan terhadap kepuasan nasabah sebesar 0,000 . Nilai signifikasi $0,000<0,05$, dengan demikian dapat diartikan bahwa kemitraan berpengaruh terhadap kepuasan nasabah. Dengan demikian dapat disimpulkan bahwa Ho ditolak dan $\mathrm{Ha}$ diterima, sehingga hipotesis yang menyatakan dugaan adanya pengaruh kemitraan terhadap kepuasan nasabah dapat diterima

\section{Pengaruh kemitraan terhadap loyalitas nasabah}

Berdasarkan hasil pengolahan SPSS, di peroleh nilau signifikasi pengaruh kemitraan terhadap loyalitas nasabah sebesar 0,017. Nilai signifikasi $0,017<0,05$, dengan demikian dapat diartikan bahwa kemitraan berpengaruh terhadap loyalitas nasabah. Dengan demikian dapat disimpulkan bahwa Ho ditolak dan $\mathrm{Ha}$ diterima, sehingga 
hipotesis yang menyatakan dugaan adanya pengaruh kemitraan terhadap loyalitas nasabah dapat diterima.

\section{Pengaruh kepercayaan terhadap kepuasan nasabah}

Berdasarkan hasil pengolahan SPSS, di peroleh nilau signifikasi pengaruh kepercayaan terhadap kepuasan nasabah sebesar 0,024. Nilai signifikasi 0,024< 0,05 , dengan demikian dapat diartikan bahwa kepercayaan berpengaruh terhadap kepuasan nasabah. Dengan demikian dapat disimpulkan bahwa Ho ditolak dan $\mathrm{Ha}$ diterima, sehingga hipotesis yang menyatakan dugaan adanya pengaruh kepercayaan terhadap kepuasan nasabah dapat diterima

\section{Pengaruh kepercayaan terhadap loyalitas nasabah}

Berdasarkan hasil pengolahan SPSS, di peroleh nilau signifikasi pengaruh kepercayaan terhadap loyalitas nasabah sebesar 0,007. Nilai signifikasi 0,007< 0,05 , dengan demikian dapat diartikan bahwa kepercayaan berpengaruh terhadap loyalitas nasabah. Dengan demikian dapat disimpulkan bahwa Ho ditolak dan $\mathrm{Ha}$ diterima, sehingga hipotesis yang menyatakan dugaan adanya pengaruh kepercayaan terhadap loyalitas nasabah dapat diterima.

\section{Pengaruh komplain konflik terhadap kepuasan nasabah}

Berdasarkan hasil pengolahan SPSS, di peroleh nilau signifikasi pengaruh komplain konflik terhadap kepuasan nasabah sebesar 0,030. Nilai signifikasi $0,030<0,05$, dengan demikian dapat diartikan bahwa komplain konflik berpengaruh terhadap kepuasan nasabah. Dengan demikian dapat disimpulkan bahwa Ho ditolak dan $\mathrm{Ha}$ diterima, sehingga hipotesis yang menyatakan dugaan adanya pengaruh komplain konflik terhadap kepuasan nasabah dapat diterima

\section{Pengaruh komplain konflik terhadap loyalitas nasabah}

Berdasarkan hasil pengolahan SPSS, di peroleh nilau signifikasi pengaruh komplain konflik terhadap loyalitas nasabah sebesar 0,016 . Nilai signifikasi $0,016<0,05$, dengan demikian dapat diartikan bahwa komplain konflik berpengaruh terhadap loyalitas nasabah. Dengan demikian dapat disimpulkan bahwa Ho ditolak dan $\mathrm{Ha}$ diterima, sehingga hipotesis yang menyatakan dugaan adanya pengaruh komplain konflik terhadap loyalitas nasabah dapat diterima.

\section{Pengaruh kualitas komunikasi terhadap kinerja SDM melalui motivasi intrinsik}

Nilai pengaruh langsung kualitas komunikasi terhadap kinerja SDM sebesar 0,415 lebih besar dibandingkan dengan pengaruh tidak langsung sebesar $0,059(0,493 \times 0,135)$, dengan demikian dalam penelitian ini kualitas komunikasi berpengaruh langsung terhadap kinerja SDM tidak melalui motivasi intrinsik. Dengan demikian motivasi intrinsik bukan merupakan variabel intervening di antara pengaruh kualitas komunikasi terhadap kinerja SDM.

\section{Pengaruh Langsung dan Tidak Langsung \\ Pengaruh langsung atau tidak langsung dopergunakan untuk menguji apakah variabel kepuasan nasabah sebagai variabel intervening atau tidak. Hasil pengujian adalah sebagai berikut:}

\section{Pengaruh komunikasi terhadap loyalitas nasabah melalui kepuasan nasabah}

Nilai pengaruh langsung komunikasi terhadap loyalitas nasabah sebesar 0,131 lebih besar dibandingkan dengan pengaruh tidak langsung sebesar $0,083 \quad(0,217 x$ $0,393)$, dengan demikian dalam penelitian ini komunikasi berpengaruh langsung terhadap loyalitas nasabah tidak melalui kepuasan nasabah. Dengan demikian kepuasan nasabah bukan merupakan variabel 
intervening di antara pengaruh komunikasi terhadap loyalitas nasabah.

\section{Pengaruh kemitraan terhadap loyalitas nasabah melalui kepuasan nasabah}

Nilai pengaruh langsung kemitraan terhadap loyalitas nasabah sebesar 0,108 lebih kecil dibandingkan dengan pengaruh tidak langsung sebesar $0,162 \quad(0,412 \times$ $0,393)$, dengan demikian dalam penelitian ini kemitraan berpengaruh tidak langsung terhadap loyalitas nasabah melalui kepuasan nasabah. Dengan demikian kepuasan nasabah merupakan variabel intervening di antara pengaruh kemitraan terhadap loyalitas nasabah.

\section{Pengaruh kepercayaan terhadap loyalitas nasabah melalui kepuasan nasabah}

Nilai pengaruh langsung kepercayaan terhadap loyalitas nasabah sebesar 0,143 lebih besar dibandingkan dengan pengaruh tidak langsung sebesar $0,082 \quad(0,209 x$ $0,393)$, dengan demikian dalam penelitian ini kepercayaan berpengaruh langsung terhadap loyalitas nasabah tidak melalui kepuasan nasabah. Dengan demikian kepuasan nasabah bukan merupakan variabel intervening di antara pengaruh kepercayaan terhadap loyalitas nasabah.

\section{Pengaruh komplain konflik terhadap loyalitas nasabah melalui kepuasan nasabah}

Nilai pengaruh langsung komplain konflik terhadap loyalitas nasabah sebesar 0,109 lebih besar dibandingkan dengan pengaruh tidak langsung sebesar $0,048 \quad(0,122 \times$ 0,393 ), dengan demikian dalam penelitian ini komplain konflik berpengaruh langsung terhadap loyalitas nasabah tidak melalui kepuasan nasabah. Dengan demikian kepuasan nasabah bukan merupakan variabel intervening di antara pengaruh komplain konflik terhadap loyalitas nasabah.

\section{Pembahasan}

Komunikasi berpengaruh terhadap kepuasan nasabah dan loyalitas nasabah, dengan arah regresi positif, artinya apabila komunikasi semakin meningkat, yaitu komunikasi timbal balik yang dilakukan BPR Argodana Pudakpayung Semarang kepada nasabahnya, kemudahan dimengerti bahasa yang dipergunakan untuk berkomunikasi dengan nasabah, dan kesopanan bahasa yang dipergunakan petugas pelayanan untuk berkomunikasi, maka kepuasan nasabah dan loyalitas nasabah semakin meningkat. Kondisi ini terjadi karena dalam kegiatan bisnis, komunikasi pemasaran adalah sangat penting, karena dengan komunikasi terjadi pertukaran informasi yang membuat nasabah merasa yakin dan puas atas bank tersebut. Selain itu komunikasi juga untuk mempertahankan pelanggan lama dan menarik pelanggan baru perusahaan harus melakukan komunikasi yang sesuai dengan karakter konsumen sasarannya. Hasil ini mendukung penelitian Murti (2013), Ellena (2011), yang membuktikan bahwa komunikasi berpengaruh positif terhadap kepuasan konsumen dan loyalitas nasabah.

Kemitraan berpengaruh terhadap kepuasan nasabah dan loyalitas nasabah, dengan arah regresi positif, artinya apabila kemitraan semakin meningkat, yaitu perasaan bangga bisa menjadi nasabah BPR Argodana Pudakpayung Semarang, jalinan hubungan BPR Argodana Pudakpayung Semarang dengan nasabah melalui pertemuan, dan perhatian BPR Argodana Pudakpayung Semarang terhadap setiap dana yang disimpan oleh nasabah, maka kepuasan nasabah dan loyalitas nasabah semakin meningkat. Kondisi ini terjadi karena konsumen merasakan sejumlah perasaan terhadap kemitraan pada hubungan yang telah tercipta dengan para penyedia jasa. Kemitraan dalam konsep long term relationship, memegang peranan yang sangat penting karena hubungan jangka panjang paling banyak didasarkan kepada komitmen kedua belah pihak. Hasil ini mendukung penelitian Murti (2013), Ellena (2011), yang membuktikan bahwa 
kemitraan berpengaruh positif terhadap kepuasan konsumen dan loyalitas nasabah.

Kepercayaan berpengaruh terhadap kepuasan nasabah dan loyalitas nasabah, dengan arah regresi positif, artinya apabila kepercayaan semakin meningkat, yaitu reputasi produk BPR Argodana Pudakpayung Semarang cukup terpercaya, pemberian jaminan kenyamanan dan keamanan dana yang disimpan oleh nasabah, dan manfaat yang dapat diterima dari produk yang ditawarkan oleh BPR Argodana Pudakpayung Semarang, maka kepuasan nasabah dan loyalitas nasabah semakin meningkat. Kondisi ini terjadi karena kepercayaan atas merek akan berpengaruh terhadap kepuasan dan loyalitas hal ini dikarenakan kepercayaan menimbulkan suatu hubungan timbal balik yang bernilai sangat tinggi. Jadi dapat dikatakan bahwa kepuasan dan loyalitas adalah proses yang kesinambungan sebagai akibat dari terbentuknya kepercayaan atas merek. Hasil ini mendukung penelitian Murti (2013), Septria (2012), yang membuktikan bahwa kepercayaan berpengaruh positif terhadap kepuasan konsumen dan loyalitas nasabah.

Komplain konflik berpengaruh terhadap kepuasan nasabah dan loyalitas nasabah, dengan arah regresi positif, artinya apabila komplain konflik semakin meningkat, yaitu empati perusahaan terhadap pelanggan yang marah, kecepatan perusahaan dalam menangani keluhan pelanggan, dan kemudahan bagi konsumen untuk menghubungi perusahaan, maka kepuasan nasabah dan loyalitas nasabah semakin meningkat. Kondisi ini terjadi karena pada hakekatnya ada dua tujuan utama pelanggan menyampaikan komplain. Pertama, untuk menutupi kerugian ekonomis, yang biasanya diwujudkan dengan melakukan voice response atau third party response. Tujuan kedua adalah untuk memperbaiki citra diri (self-image). Apabila citra diri pelanggan berkaitan erat dengan pembelian produk tertentu, maka ketidakpuasan terhadap produk yang dibeli tersebut akan menurunkan citra diri pelanggan yang bersangkutan untuk mengangkat kembali citra dirinya, maka pelanggan tersebut biasanya melakukan tindakan-tindakan voice response atau third party response. Hasil ini mendukung penelitian Murti (2013) yang membuktikan bahwa kepercayaan berpengaruh positif terhadap kepuasan konsumen dan loyalitas nasabah.

Kepuasan nasabah berpengaruh terhadap loyalitas nasabah, dengan arah regresi positif, artinya apabila kepuasan nasabah semakin meningkat, yaitu kesesuaian jasa pelayanan yang diterima dari BPR Argodana Pudakpayung Semarang dengan harapan, kecocokkan atas pelayanan yang diberikan BPR Argodana Pudakpayung Semarang, dan akan menggunakan jasa lain yang disediakan oleh BPR Argodana Pudakpayung Semarang, maka loyalitas nasabah semakin meningkat. Kondisi ini terjadi karena kepuasan nasabah merupakan konsep yang penting dalam pemasaran dan penilaian konsumen. Sudah menjadi pendapat umum bahwa jika konsumen puas dengan suatu produk atau merek cenderung akan terus membeli dan menggunakannya terus memberi tahu orang lain tentang pengalaman yang menyenangkan dengan produk atau jasa tersebut. Hasil ini mendukung penelitian Murti (2013) yang membuktikan bahwa kkepuasan konsumen berpengaruh positif terhadap loyalitas nasabah.

\section{SIMPULAN}

Berdasarkan penelitian yang telah dilakukan, maka dapat dibuat kesimpulan sebagai berikut :

Komunikasi berpengaruh terhadap kepuasan nasabah dan loyalitas nasabah, dengan arah regresi positif, artinya apabila komunikasi semakin meningkat, yaitu komunikasi timbal balik yang dilakukan BPR Argodana Pudakpayung Semarang kepada nasabahnya, kemudahan dimengerti bahasa yang dipergunakan untuk berkomunikasi dengan nasabah, dan kesopanan bahasa 
yang dipergunakan petugas pelayanan untuk berkomunikasi, maka kepuasan nasabah dan loyalitas nasabah semakin meningkat.

Kemitraan berpengaruh terhadap kepuasan nasabah dan loyalitas nasabah, dengan arah regresi positif, artinya apabila kemitraan semakin meningkat, yaitu perasaan bangga bisa menjadi nasabah BPR Argodana Pudakpayung Semarang, jalinan hubungan BPR Argodana Pudakpayung Semarang dengan nasabah melalui pertemuan, dan perhatian BPR Argodana Pudakpayung Semarang terhadap setiap dana yang disimpan oleh nasabah, maka kepuasan nasabah dan loyalitas nasabah semakin meningkat

Kepercayaan berpengaruh terhadap kepuasan nasabah dan loyalitas nasabah, dengan arah regresi positif, artinya apabila kepercayaan semakin meningkat, yaitu reputasi produk BPR Argodana Pudakpayung Semarang cukup terpercaya, pemberian jaminan kenyamanan dan keamanan dana yang disimpan oleh nasabah, dan manfaat yang dapat diterima dari produk yang ditawarkan oleh BPR Argodana Pudakpayung Semarang, maka kepuasan nasabah dan loyalitas nasabah semakin meningkat.

Komplain konflik berpengaruh terhadap kepuasan nasabah dan loyalitas nasabah, dengan arah regresi positif, artinya apabila komplain konflik semakin meningkat, yaitu empati perusahaan terhadap pelanggan yang marah, kecepatan perusahaan dalam menangani keluhan pelanggan, dan kemudahan bagi konsumen untuk menghubungi perusahaan, maka kepuasan nasabah dan loyalitas nasabah semakin meningkat.

Kepuasan nasabah berpengaruh terhadap loyalitas nasabah, dengan arah regresi positif, artinya apabila kepuasan nasabah semakin meningkat, yaitu kesesuaian jasa pelayanan yang diterima dari BPR Argodana Pudakpayung Semarang dengan harapan, kecocokkan atas pelayanan yang diberikan BPR Argodana Pudakpayung Semarang, dan akan menggunakan jasa lain yang disediakan oleh BPR Argodana Pudakpayung Semarang, maka loyalitas nasabah semakin meningkat.

Kepuasan nasabah merupakan variabel intervening di antara pengaruh kemitraan terhadap loyalitas nasabah, namun demikian kepuasan nasabah bukan variabel intervening di antara pengaruh komunikasi, kepercayaan dan komplain konflik terhadap loyalitas nasabah.

Berdasarkan kesimpulan yang telah dikemukakan, maka diberikan beberapa saran sebagai berikut :

Memberikan pengarahan kepada karyawan untuk bisa memberikan pelayanan yang optimal, membawa alat komunikasi dimana saja, sehingga pada saat konsumen membutuhkan komplain bisa cepat di atasi.

Pihak BPR bisa menjaga kemitraan dengan pelanggan, hal ini dilakukan dengan cara memberikan kenang-kenangan yang bagus kepada pelanggan agar tetap berkomitmen kepada perusahaan

\section{DAFTAR PUSTAKA}

Ellena, F. (2013). Analisis Pengaruh Kepercayaan, Komitmen, Komunikasi dna Penangangan Keluhan Terhadap Loyalitas Nasabah. Jurnal Ekonomi Undip.

Tjptono, F. (2010). Manajemen Jasa, Yogyakarta: Andi Ofset,.

Samuel, H. (2012). Customer Relationship Marketing Pengaruhnya Terhadap Kepercayaan dan Loyalitas Perbankan Nasional. Jurnal Manajemen Pemasaran, 7(1), ISSN 1907-235X.

Umar, H. (2002). Riset Pemasaran dan Perilaku Konsumen, Edisi Kedua, Jakarta : Gramedia Pustaka Utama. 
Kotler, P. (2010). Manajemen Pemasaran. Jakarta: Internusa.

Singarimbun, M., Effendi, S. (2005). Metode Penelitian Survey. Jakarta: LP3ES.

Maulidi., Rofiq, A. (2012). Pengaruh Relationship Marketing Terhadap Loyalitas Nasabah Studi Pada Nasabah PT. Bank Pembangunan Daerah Jawa Timur Tbk Cabang Bawen. Jurnal Manajemen Universitas Brawijaya Malang.

Hadinata, M. (2013). Studi Pengaruh Trust, Commitmen, Comunication, Conflict Handing terhadap Customer Loyalty di Bank Mandiri Surabaya. Jurnal Ilmiah Mahasiswa Surabaya, 2 (1).

Purwanto. (2013). Analisis Relationship Marketing Terhadap Loyalitas Nasabah. Jurnal Ekonomi Undip.

Murti, S. H. (2013). Pengaruh Relationship Marketing Terhadap Loyalitas Pelanggan. Jurnal Unnes, (1), ISSN 2552-6552. 